\title{
Isolation and Characterization of a Novel Bacterium, Bacillus subtilis HR-1019, with Insoluble Phosphates Solubilizing Activity
}

\author{
Yong-Suk Lee', Dong-Ju Park', Jae Hoon Kim², Hyeong Seok Kim² and Yong-Lark Choi ${ }^{1}$ * \\ ${ }^{1}$ Department of Biotechnology, College of Natural Resources and Life Science, Dong-A University, Busan 604-714, Korea \\ ${ }^{2}$ Haerim Pharmetic LTD, Busan 617-736, Korea
}

Received November 29, 2012 /Revised January 24, 2013 / Accepted January 25, 2013

\begin{abstract}
The objective of this study was to develop a mineral phosphate-solubilizing bacterium as a biofertilizer. A mineral phosphate-solubilizing bacterium HR-1019 was isolated from cultivated soils. It was identified as Bacillus subtilis by $16 \mathrm{~S}$ rDNA analysis. The phosphate-solubilizing activities of the HR-1019 strain against three types of insoluble phosphate, hydroxyapatite, tri-calcium phosphate, and aluminum phosphate were quantitatively determined. When $5 \%$ of glucose concentration was used as a carbon source, the strain showed marked mineral phosphate-solubilizing activity. Mineral phosphate solubilization was directly related to $\mathrm{pH}$ drop in the culture solution of the strain. The pathogenic activity and antifungal effects of the HR-1019 strain were measured inclear zones formed in PDA media.
\end{abstract}

Key words : Insoluble phosphate, mineral phosphate-solubilization, free phosphate, Bacillus subtilis HR-1019, plant pathogen

\section{서 론}

작물의 3 대 영양소 중의 하나인 인은 토양에는 대부분이 불용성 형태로 존재하기 때문에 식물의 이용이 어려워서 미생 물 생태학자들은 tri-calcium phosphate 또는 hydroxy-apatite 와 같은 불완전 용해 무기 인산 융해 미생물에 큰 능력에 관심 을 가져 왔었다[3].

인은 식물체에서 생물학적 성장과 발육에 필수적인 영양성 분이며 핵산, 인지질, phytates 등의 중요 구성성분이며, 식물 및 박테리아 성장에 필요한 에너지 대사에서도 중요한 역할을 하는 원소이다. 그러나 인산은 산성토양에서는 철 및 알루미 늄 이온과 알칼리성 토양에서는 칼슘이온과 쉽게 결합하여 불용화 됨으로써 토양 중에는 식물이 이용할 수 없는 불용성 인산의 양만 증가되는 결과를 가져다준다. 실제로 인산은 토 양 중 $0.05 \%(\mathrm{w} / \mathrm{w})$ 를 차지하고 있으나, 식물이나 미생물이 이용할 수 있는 인산양은 그 중에서도 $0.1 \%$ 이다[11]. 난용성 인산염을 식물이나 미생물이 이용하기 쉬운 $\mathrm{H}_{2} \mathrm{PO}^{4}$ 나 $\mathrm{HPO}_{4}^{2-}$ 의 이온형태로 전환시켜주는 과정을 가용화라 하며 토양 속에 는 이러한 가용화 반응을 일으키는 미생물이 많이 존재한다고 보고되어져 있다[12]. Illmer와 Schinner는 몇몇 PSM (phosphate solubilizing microorganism)이 칼슘-인산(Ca-Ps)

\section{*Corresponding author}

Tel : +82-51-200-7585, Fax : +82-51-200-6536

E-mail : ylchoi@dau.ac.kr

This is an Open-Access article distributed under the terms of the Creative Commons Attribution Non-Commercial License (http://creativecommons.org/licenses/by-nc/3.0) which permits unrestricted non-commercial use, distribution, and reproduction in any medium, provided the original work is properly cited.
을 용해시키는데 있어서 매우 효과적임을 보여주었다[5].

인산 가용화 균을 이용한 환경친화형 생물비료(biofertilizers) 의 개발노력은 부단히 이루어져 왔으며, 인산의 흡수를 증대 시켜 작물의 수량증가를 보여준 연구결과도 있다[2, 8].

국내에서의 미생물을 이용한 생물비료의 개발은 균주 선발, 배양특성 및 식물재배 효과에서 연구가 수행되었으나, 인산염 가용화 관련 유전자 연구의 유전학적인 접근은 아직 미흡하다 [18]. 인산가용화의 기작은 가용화균이 생산하는 글루코닉산 과 같은 유기산의 생성에 의한 것이라는 보고가 Burkholderia sp., Aeromonas sp. 등에서 알려져 있다[15, 16].

이미 보고되어진 인산가용화균으로는 Bacillus megaterium, B. polymyxol, Pseudomonas striata, Pseudomonas sp. (P118/89) 등의 세균이 알려져 있으며[1, 2, 5, 19], Penicillium simplicisimaum, P.aurantiogriseum, P. bilaji, Aspergillus awamori, A. aculeatus, A. niger 등이 있다[6, 14, 20]. 환경보전을 위한 노력으로 화학비료에 대한 제약이 심화될 것으로 판단되기 때문에 난용성 인산염을 효율적으로 분해하여 인산질 비료 성분을 충분히 공급해줄 수 있는 토양미생물의 탐색과 생물 비료의 개발은 시급히 해결해야 할 과제다. 그러나 알려진 인산가용화 세균을 이용한 미생물비료의 개발 시에는 장기 간 안정적인 생존 상태를 유지시키기가 어려운 것들이 알려 져 있다[1, 2, 5, 15, 16, 19].

따라서 본 연구의 목적은 난용성 인산염을 가용화 시킬 수 있는 경제적이고, 고효율적인 생물비료의 개발을 위한 것이다. 미생물제제 개발 시에 제제의 균주 생존 안정성이 비교적 우수 미생물인 Bacillus 속을 분리하여 동정하였기에, 선발된 미생물 의 배양학적 특성에 따른 난용성 인산가용화를 조사하였다. 


\section{재료 및 방법}

\section{인산가용화균의 분리 및 동정}

김해시 대동면 인근의 인산집적이 심한 시설 비닐하우스에 서 채취한 토양 $10 \mathrm{~g}$ 를 $100 \mathrm{ml}$ 의 멸균수에 넣고 $200 \mathrm{rpm}$ 으로 30 분 동안 혼합한 후, 희석 평판법으로 6 단계까지 희석한 시료 를 LB 배지에 도말 하였다. 생성된 콜로니를 $0.5 \%$ tri-calcium phosphate가 함유된 sucrose minimal (SM) 고체배지(sucrose $10 \mathrm{~g}, \mathrm{HH}_{4} \mathrm{NO}_{3} 0.27 \mathrm{~g}, \mathrm{KCl} 0.2 \mathrm{~g}, \mathrm{MgSO}_{4} \cdot 7 \mathrm{H}_{2} \mathrm{O} 0.1 \mathrm{~g}, \mathrm{MnSO}_{4}$ - $6 \mathrm{H}_{2} \mathrm{O} 1 \mathrm{mg}, \mathrm{FeSO}_{4} \cdot 7 \mathrm{H}_{2} \mathrm{O} 1 \mathrm{mg}$, Yeast extract $0.1 \mathrm{~g}$, 난용성 인산염 $5 \mathrm{~g}$, agar $1.2 \%, \mathrm{H}_{2} \mathrm{O} / 1$ l)에 접종하여 $27^{\circ} \mathrm{C}, 3$ 일간 배양 하여 투명대(clear zone)를 형성하는 균주를 선발하였다[11]. 선발된 균주는 단일 콜로니가 생성되도록 수차례 계대 배양을 실시하였다. 난용성 인산염 가용화능이 확인된 인산가용화균 을 동정하기 위하여 동정을 위하여 멸균된 $1.5 \mathrm{ml}$ 원심분리 튜브에 $0.5 \mathrm{ml}$ 멸균 생리식염수와 균주를 혼합하여 10,000 $\mathrm{rpm}$ 으로 10 분간 원심분리하고 상등액을 제거 한 후 $16 \mathrm{~S}$ $\mathrm{rDNA}$ 를 증폭하기 위해서 두 개의 올리고 뉴클레오타이드 프 라이머 5'-GAGTTTGATCCTGGCTCAG-3' (position 9 to 27 E. coli 16s rDNA), 5'-A GAAAGGAGGTGATCCAGCC-3' (position 1,542 to 1,525 E. coli $16 \mathrm{~S} \mathrm{rDNA}$ )를 이용하였으며, $\mathrm{rpoB}$ 유전자의 증폭을 위해서 두 개의 프라이머 5'AACCAGT TCCTCGTTGGCCTGG-3', $5^{\prime}$-CCTGAACAACACGCTCGGA $-3^{\prime}$ 을 사용하였다[10]. 증폭된 $16 \mathrm{~S} \mathrm{rRNA}$ 유전자의 염기서열을 분석한 후 NCBI (National Center for Biotechnology Information)의 데이터베이스(http://www.ncbi.nlm)에서 BLAST 로 검색하여 기존에 보고된 미생물의 $16 \mathrm{~S} \mathrm{rRNA}$ 와 상동성을 비교하였다.

\section{인산가용화능 측정}

난용성인산염이 $0.5 \%$ 첨가된 $\mathrm{SM}$ 배지 $100 \mathrm{ml}$ 에 전배양한 균주 $1 \%$ 를 식균한 후에, $37^{\circ} \mathrm{C}, 160 \mathrm{rpm}$ 으로 필요한 시간 동안 진탕 배양한 배양액을 원심분리로 얻어낸 상등액 내의 유리인 산 농도와 $\mathrm{pH}$ 변화를 일정시간에 측정하였다. 즉, 균체 배양액 $1 \mathrm{ml}$ 을 소형 튜브에 담은 후 소형원심분리기로 $13,000 \mathrm{rpm}$, 5 분간 실온에서 원심분리 하였다. 원심분리 후 상등액 $10 \mu \mathrm{l}$ 을 취하고 여기에 멸균수 $90 \mu 1$ 을 첨가하여 총 $100 \mu 1$ 이 되게 하고, 여기에 phosphorus reagent $900 \mu 1$ 을 첨가하여 혼합한 후 15 분 간 실온에서 방치한 다음, $340 \mathrm{~nm}$ 에서 흡광도를 측정하였다 [15]. 이때 실험에 사용한 용액은 Sigma사에서 제조한 phosphate reagent kit를 사용하였다.

\section{배양 조건에 따른 인산가용화 특성 조사}

분리한 인산가용화균 Bacillus subtilus HR-1019 균주를 배양 온도, 배양액의 $\mathrm{pH}$ 및 탄소원의 차이에 따른 난용성 인산염 가용화능의 차이를 조사하였다. 배양온도 차이에 따른 영향은 $26^{\circ} \mathrm{C}, 30^{\circ} \mathrm{C}, 37^{\circ} \mathrm{C}$ 에서 실시하였고, 배지의 초기 배양 $\mathrm{pH}$ 에 따 른 영향은 $\mathrm{pH} 5.0,6.0,7.0$ 에서 실시하였다. 배지 조성의 차이 에 따른 영향은 $37^{\circ} \mathrm{C}$, 초기배양 $\mathrm{pH} 6.0$ 에서 glucose를 $1 \%, 3 \%$, $5 \%$ 농도별로 첨가하여 실시하였다. 균주에 의한 $\mathrm{pH}$ 변화와 유리 인산 생성능은 매 12시간마다 측정하였으며, 이상의 배 양 환경에 관한 모든 실험은 3회 반복 수행하여 평균값을 구함 으로서 실험 오차를 최소화하였다.

\section{난용성 인산염 종류에 따른 인산가용화 특성 조사}

분리한 인산가용화균 Bacillus subtilus HR-1019 균주의 난용 성 인산염 종류에 따른 난용성 인산염 가용화능의 차이를 조 사하였다. 즉, 3 종류의 난용성 인산염, tri-calcium phosphate, hydroxy apatite 및 aluminuim phosphate가 $0.5 \%$ 함유된 SM 배지, $\mathrm{pH}$ 6.0에서 12 시간마다 분리 균주의 인산가용화능 및 $\mathrm{pH}$ 변화를 측정하였다.

\section{분리 균의 항균 스펙트럼}

분리 균주를 이용해 농작물 재배에 피해를 크게 주는 병원 균, 잿빛 곰팡이 병원균인 Botrysis cinerea, 줄기썩음병 원균인 Rhizoctonia solani 및 균핵병원균인 Sclerotinia sclerotiorum 등 에 대하여 PDA plate 대치배양법으로 항균력을 조사하였다. 배지에 병원균과 HR-1019 균주를 동시에 접종하여 $30^{\circ} \mathrm{C}$ 에서 3-6일간 배양한 후에 저해 정도를 측정하여 항균 스펙트럼을 조사하였다 $[8,9]$

\section{결과 및 고찰}

\section{인산가용화균의 분리 및 동정}

김해시 대동면 인근의 시설 비닐하우스에서 채취한 인산집 적이 심한 토양을 희석 평판법으로 분석한 세균 수는 건조 토양 $1 \mathrm{~g}$ 당 $1 \sim 3 \times 10^{8} \mathrm{cfu}$ 였다. 콜로니의 모양, 색깔 등으로 보아 바실러스 속으로 보이는 것을 tri-calcium phosphate가 함유된 $\mathrm{SM}$ 고체배지 상에 접종하여 배양하였다. 3 일 후에 투명대를 관찰하여 비교적 투명대 영역이 분명하게 나타난 균주를 선별 하였다. 선별된 균주는 인산염 첨가 배지에서 유리 인산 생성 량이 비교적 높은 수준의 세균을 선발하였으며, 그 중에서 인 산가용화 능이 우수한 HR-1019 균주를 계속하여 실험하였다.

우선 분리 균주를 동정하기 위하여 그람 염색, 현미경 관찰 등의 생리 생화학적인 특성으로 포자형성능과 형태적 특성으 로 Bacillus 속으로 추정하였다(data not shown). 보다 정확한 유전학적 분류를 보고자 $16 \mathrm{~S}$ rRNA sequencing 분석방법을 통하여 동정을 실시한 결과 본 미생물은 Bacillus subtilis와 $98 \%$ 의 일치성을 나타내어 최종적으로 Bacillus subtilis HR1019로 동정되었다. 


\section{온도 변화에 따른 인산가용화능력}

분리균주 Bacillus $s p$. HR-1019 균주의 미생물 처리제 개발을 위하여 자연 환경 조건에서 생육과 높은 인산 가용화능력을 가지는 조건은 매우 중요하다. 사용균주는 인산염을 넣고 배 양한 배양액이 $\mathrm{pH}$ 가 많이 감소한 것은 물론 유리인산의 분해 능도 우수하였다. 이러한 결과는 기존의 인산가용화능이 우수 한 균주에 비하여 다소 떨어지는 능력이나, 균주의 장기보존 안정성이 매우 우수할 것이라는 Bacillus 속이라는 점을 고려 하면 매우 긍정적인 결과였다. 따라서 이 균주의 온도 변화에 따른 가용화 능을 시험한 결과는 Fig. 1에 나타냈다. 배양 시간 이 경과함 에 따라 $\mathrm{pH}$ 감소의 경향과 차이가 뚜렷하게 나타났 다. 가장 $\mathrm{pH}$ 가 많이 감소한 것은 $37^{\circ} \mathrm{C}$ 이었다. $37^{\circ} \mathrm{C}$ 에서는 초기 에 $\mathrm{pH}$ 가 4.7 정도까지 떨어지고 120 시간 측정이 끝날 때까지 그 값을 유지했다. $42^{\circ} \mathrm{C}$ 도 초반에 5.2 정도까지 감소하여 그 값이 유지된다. $30^{\circ} \mathrm{C}$ 에서도 $\mathrm{pH}$ 값이 5.0 정도로 $42^{\circ} \mathrm{C}$ 와 $37^{\circ} \mathrm{C}$ 의 중간 값이고. 또 그 값을 계속해서 유지해 가다 84시간을 기준 으로 하여 $\mathrm{pH}$ 값이 다소 증가하는 경향을 보였다. 이러한 결과 는 $\mathrm{pH}$ 값의 감소로 보았을 때 $37^{\circ} \mathrm{C}$ 에서 가장 활성이 좋음을 알 수 있다. 온도에 따른 유리 인산의 생성량은 크게 차이가

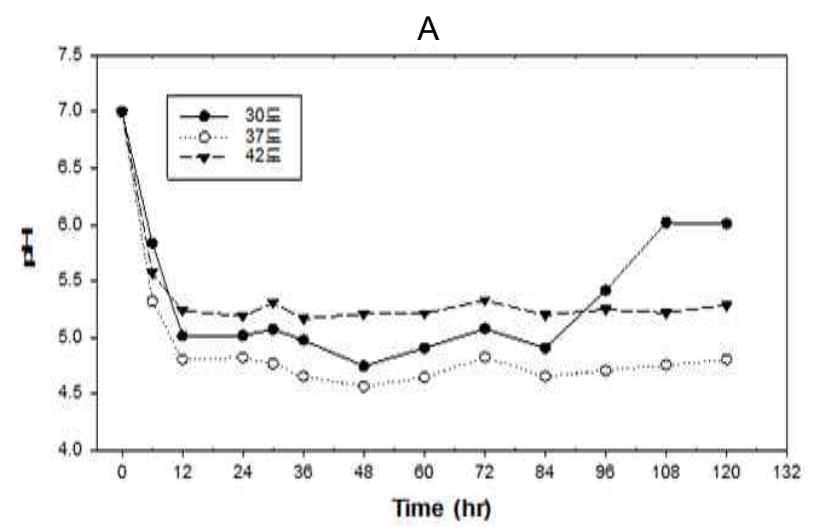

B

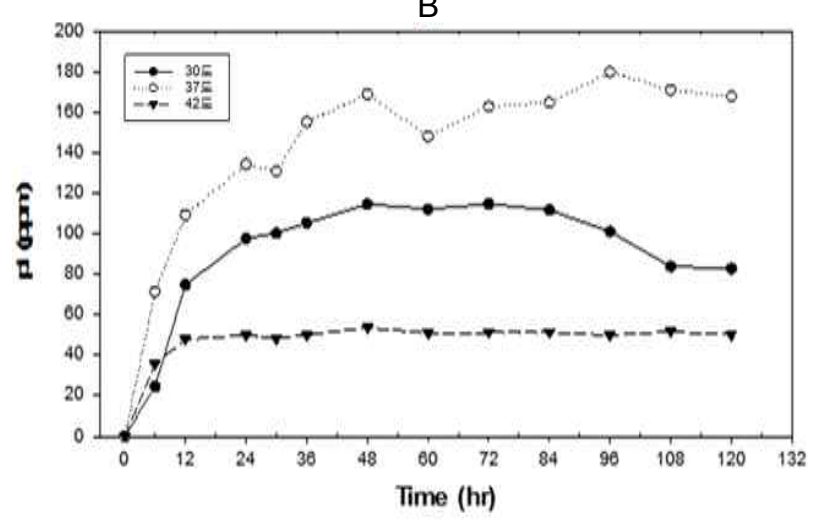

Fig. 1. Effect of temperature on the changes of free phosphate concentration and $\mathrm{pH}$ values during the cultivation of Bacillus subtilis HR-1019. (A) $\mathrm{pH}$ value, (B) phosphorus concentration. Bacteria were cultured in minimal medium containing $0.5 \%$ tricalcium phosphate.
있음을 알 수 있다. $37^{\circ} \mathrm{C}$ 에서 가장 많은 유리인산을 생산하였 고 반면 $42^{\circ} \mathrm{C}$ 에서는 유리인산의 생성량이 가장 적었다. $37^{\circ} \mathrm{C}$ 의 경우는 48 시간 정도 배양까지 유리인산의 양이 계속해서 증가하고 그 높은 유리인산 양을 120 시간까지 유지하는 경향 이었다. $30^{\circ} \mathrm{C}$ 에서도 다소 떨어지기는 하나 높은 인산가용화능 을 보였다. 이러한 결과는 $\mathrm{pH}$ 값의 감소에 따른 유리인산의 생성능으로 보았을 때는 $37^{\circ} \mathrm{C}$ 에서 가장 활성이 좋음을 알 수 있으나, $30^{\circ} \mathrm{C}$ 에서도 활성이 다소 높은 편이여서 균주의 생육 안정성이 높은 점을 고려하면 미생물처리제로의 개발에 매우 유용할 것으로 사료되었다.

\section{탄소원 종류에 따른 인산가용화 능력}

탄소원의 종류에 따른 균주의 배양과 가용화 능에 대한 영 향을 조사한 결과를 Fig. 2에 나타냈다. Starch는 다른 C-source 에 비해서 $\mathrm{pH}$ 의 감소가 낮을 뿐 아니라 다른 조건과 다르게 $\mathrm{pH}$ 가 일정하지 않았고 또 시간이 지나면 지날수록 $\mathrm{pH}$ 가 다시 감소하는 것을 볼 수 있다. 반면 sucrose와 glucose는 초반에 4.8 정도까지 $\mathrm{pH}$ 가 감소하고, 그 값을 거의 유지했으며 시간이 지남에 따라 아주 조금씩 $\mathrm{pH}$ 가 감소하는 것을 볼 수 있다.
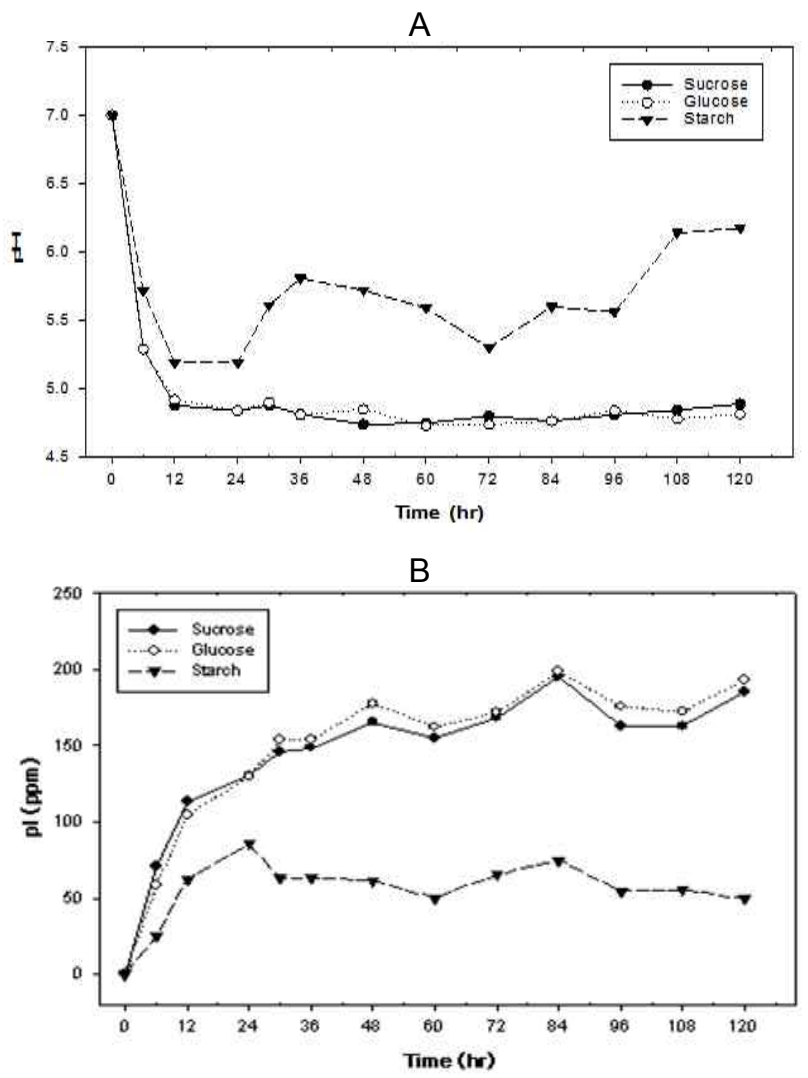

Fig. 2. Effect of carbon source on the changes of free phosphate concentration and $\mathrm{pH}$ values during the cultivation of Bacillus subtilis HR-1019. (A) pH value, (B) phosphorus concentration. Bacteria were cultured in minimal medium containing $0.5 \%$ tricalcium phosphate. 
Sucrose와 glucose는 전체적으로 비슷한 값을 가진다. 유리인 산의 생성능은 sucrose나 glucose를 탄소원으로 배양한 경우 는 인산가용화 값이 배양시간이 경과함에 따라서 조금씩 유리 인산의 양이 증가했으며, 그 전체적인 경향이 비슷하게 나타 났다. 반면 starch는 24시간까지는 유리인산의 양이 증가하다 가 $80 \mathrm{ppm}$ 정도에서 더 이상 증가하지 않고 시간이 지남에 따라 점점 떨어졌다. 유리인산의 생성량과 $\mathrm{pH}$ 저하 값으로 보았을 때 glucose와 sucroce는 거의 비슷한 활성을 나타내는 결과를 보였으나 사용이 용이한 glucose를 계속적인 가용화 특성 실험에 사용 하였다.

\section{탄소원의 농도변화에 따른 인산가용화 능력}

탄소원으로 glucose $1 \%, 3 \%, 5 \%$ 의 농도 조건에서의 인산염 가용화능을 조사한 결과를 Fig. 3 에 나타냈다. 초기에는 $1 \%$ 와 $3 \%$ 의 $\mathrm{pH}$ 값이 $5 \%$ 의 $\mathrm{pH}$ 값 보다 더 낮게 나타나는 경향이나, 배양 시간이 어느 정도 경과하면 $5 \%$ 에서는 $\mathrm{pH}$ 가 계속해서 조금씩 감소하고 $1 \%$ 와 $3 \%$ 의 $\mathrm{pH}$ 값은 일정한 값을 유지하여 30 시간이 지나면서부터는 $5 \%$ 의 $\mathrm{pH}$ 값이 $1 \%$ 와 $3 \%$ 처리구의

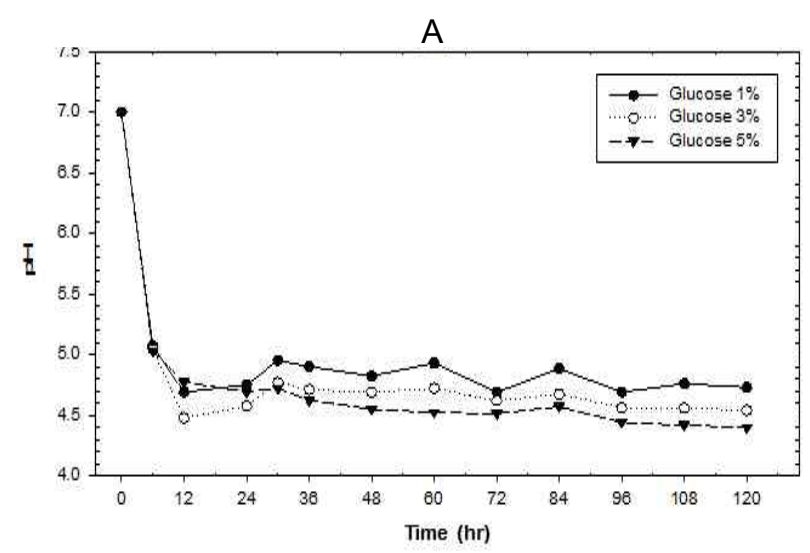

B

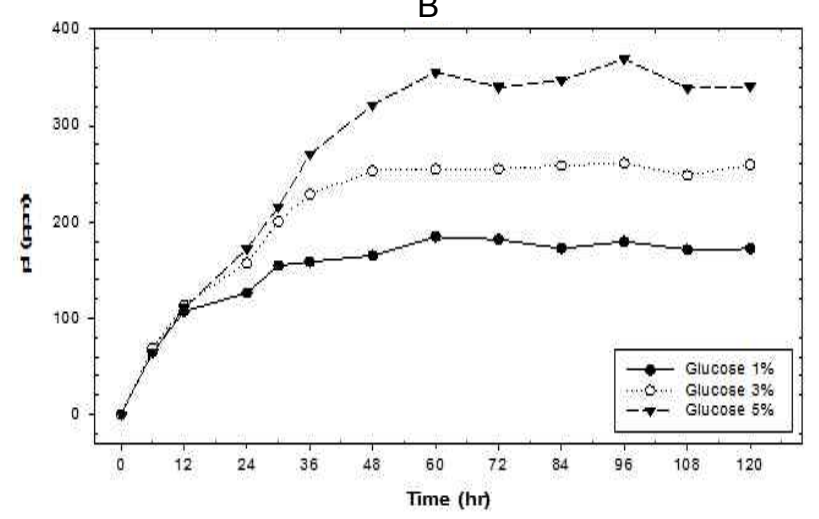

Fig. 3. Effect of glucose concentration on the changes of free phosphate concentration and $\mathrm{pH}$ values during the cultivation of Bacillus subtilis HR-1019. (A) $\mathrm{pH}$ value, (B) phosphorus concentration. Bacteria were cultured in minimal medium containing $0.5 \%$ tricalcium phosphate.
$\mathrm{pH}$ 값에 비하여 더욱 감소하였다. 하지만 농도에 따라 $\mathrm{pH}$ 의 감소량이 다르기는 하지만 같은 C-source를 사용했기 때문 인지 전체적인 $\mathrm{pH}$ 감소형태는 비슷한 것 같다. 배양 초기에 는 유리인산의 값은 아주 비슷하게 나왔다. 12시간 까지는 세 가지 조건 모두에서 비슷한 유리인산량을 나타내는 것을 알 수 있다. 하지만 그 뒤로부터 각 조건에 따른 반응이 나타 나는데. 농도가 가장 높은 $5 \%$ 에서 가장 활성이 좋게 나타난 다. 그 뒤로 $3 \%$ 와 $1 \%$ 순으로 나타나는 것이 glucose 양의 농 도가 높을수록 인산가용화능이 높게 나타났다. 배양 60 시간 에서 최대의 유리인산양을 나타냈으며 $5 \%$ 농도에서는 약 두 배 정도의 높은 값을 계속 유지하였다. 이러한 결과로 보아 사용 균주의 탄소원 농도별 인산가용화능은 농도가 $5 \%$ 정도 까지 높을수록 높게 나타나는 경향 있으나, 배양의 경제적인 조건 등을 고려한 대량 배양 조건의 탐색이 필요할 것으로 보였다.

\section{초기 $\mathrm{pH}$ 의 차이에 따른 인산가용화능력}

배양 초기 $\mathrm{pH}$ 별 인산가용화능은 6단계의 조건으로 나누 어서 실험하였다(Fig. 4). pH 5.0부터 pH 10.0까지 $\mathrm{pH}$ 값 1씩 올라가면서 인산가용화능에 따른 $\mathrm{pH}$ 값 변화를 알아보았다. 하지만 초기 $\mathrm{pH}$ 값이 현저히 다른 것에 비해 12시간쯤이 되 자 거의 모든 조건에서의 $\mathrm{pH}$ 값이 5.0 대로 떨어졌고 거의 비 슷한 양상으로 나타났다. 시간이 지남에 따라 조금씩 다른 차이가 나기 시작했으나, 일관적으로 보았을 때 거의 비슷한 수준의 $\mathrm{pH}$ 값을 가진다. 하지만 자세히 비교하여 보면, 전체 적으로 $\mathrm{pH}$ 값은 꾸준히 감소하는 경향을 보였다. 초기 $\mathrm{pH}$ 에 따른 인산가용화 결과는 실험결과 시간이 지남에 따라 유리 인산의 양이 증가하는 거의 비슷한 양상을 나타내기는 했지 만. 조금씩 초기 $\mathrm{pH}$ 값에 따라 값이 다르게 나타났다. 가장 높은 유리 인산 량을 나타낸 처리구는 초기 $\mathrm{pH}$ 값이 가장 낮 은 $\mathrm{pH} 5.0$ 이였고, 가장 낮은 유리 인산 양을 나타낸 것은 초 기 $\mathrm{pH}$ 값이 가장 높은 $\mathrm{pH} 10.0$ 에서 였다. 이러한 결과는 산 성과 알칼리의 배지 조건에서도 배양하면서 $\mathrm{pH}$ 를 저하시키 고, 인산염을 가용화 시키는 능력이 우수함으로 보아 다양한 필드 조건에서의 인산염 가용화 효과가 기대되는 균주로 평 가되어 진다.

\section{인산염의 종류에 따른 인산가용화능력}

Bacillus subtilis HR-1019의 난용성인산염의 종류에 따른 인 산가용화능을 알아보고자 사용한 난용성인산염으로는 $\mathrm{TCP}$ (tri-calcium phosphate), hydroxy apatite, aluminum phosphate의 3종류를 사용하였다.

각 난용성인산염에 따른 $\mathrm{pH}$ 저하 값은 $\mathrm{TCP}$ (tri-calcium phosphate), hydroxy apatite는 비슷한 양상으로 $\mathrm{pH}$ 가 감소한 것으로 보인다. 최대 4.3 정도까지 $\mathrm{pH}$ 가 떨어지면서 높은 활성 
A

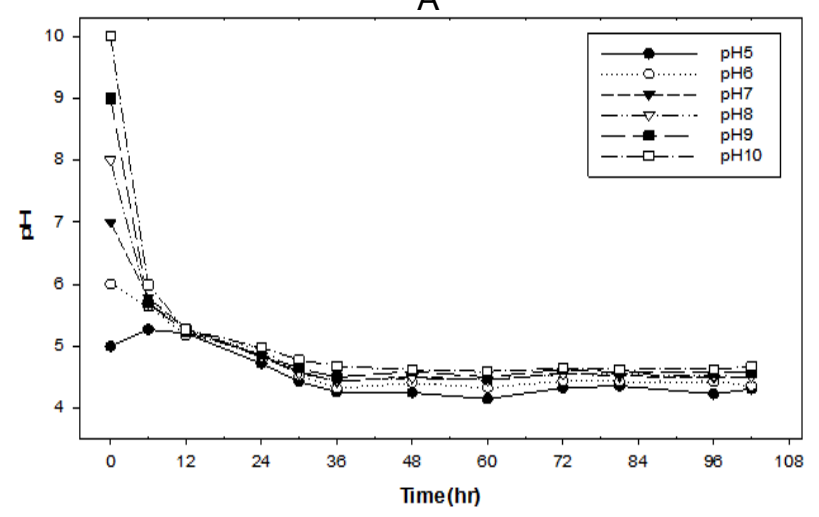

B

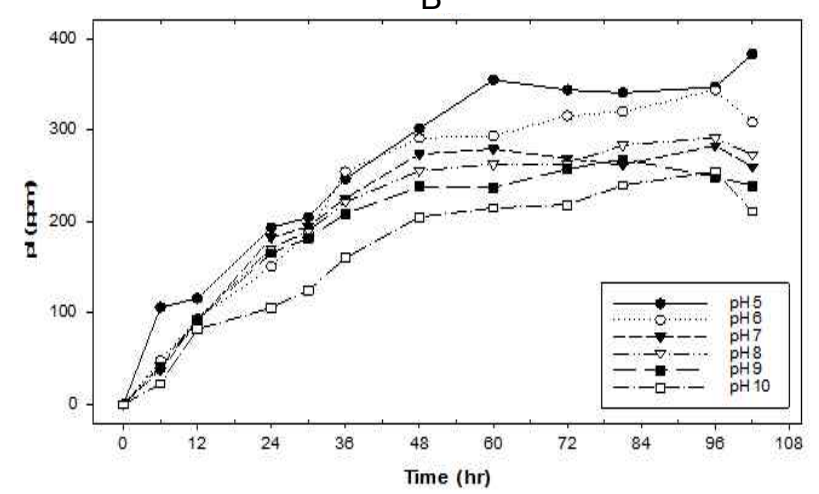

Fig. 4. Effect of initial $\mathrm{pH}$ on the changes of free phosphate concentration and $\mathrm{pH}$ values during the cultivation of Bacillus subtilis HR-1019. (A) pH value, (B) phosphorus concentration. Bacteria were cultured in minimal medium containing $0.5 \%$ tricalcium phosphate.

을 나타냄을 알 수 있다. 반면 aluminum phosphate는 다소 낮은 것으로서 어느 정도 이상 떨어지지 않음을 알 수 있다. 난용성인산염의 종류에 따른 pI값을 살펴보면 TCP, hydroxy apatite는 거의 비슷한 양상을 보이며 $400 \mathrm{ppm}$ 정도까지 증가 하였다. 반면 aluminum phosphate 처리구에서는 생성되는 유리인산의 함량이 매우 저조하였다. 이 결과는 분리균주의 인산염 용해 특성이 hydroxyapatite와 $\mathrm{TCP}$ 를 잘 분해하고, aluminum phosphate에서는 활성을 거의 나타내지 않는 것 같았다.

\section{Bacillus subtilis $\mathrm{HR}-1019$ 의 병원균에 대한 항균 효과}

본 연구에서 확보한 Bacillus subtilis HR-1019 균주를 이용하 여 식물생장 조절을 위한 다기능성을 보유한 생장조절제의 개발을 위하여 인산 가용화 능력 이외에도 식물의 병원성 균 에 대한 항균 효과의 능력을 검토하였다. 농작물 재배에 피해 를 크게 주는 병원균, 잿빛 곰팡이 병원균인 Botrysis cinerea, 줄기썩음 병원균인 Rhizoctonia solani 및 균핵 병원균인 Sclerotinia sclerotiorum 등에 대하여 PDA plate 대치배양법으
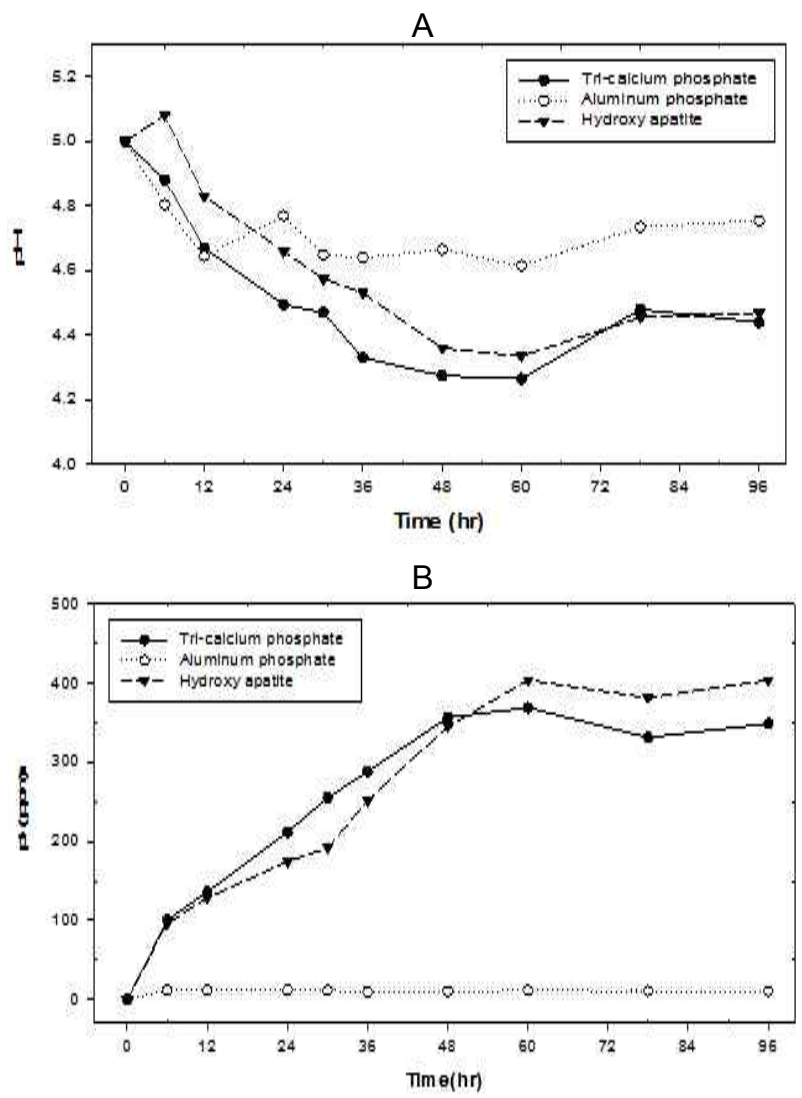

Fig. 5. Effect of the kind of insoluble phosphate on the changes of free phosphate concentration and $\mathrm{pH}$ values during the cultivation of Bacillus subtilis HR-1019. (A) $\mathrm{pH}$ value, (B) phosphorus concentration. Bacteria were cultured in minimal medium containing $0.5 \%$ tricalcium phosphate.

로 항균력을 조사하였다. 그 결과로 잿빛 곰팡이 병원균인 Botrysis cinerea, Rhizoctonia solani 및 Sclerotinia sclerotiorum의 3 종의 균주에 대하여 실험한 결과 Fig. 6 에서와 같이 병원균의 생육을 저지하는 분명한 생육저지의 clear zone을 보였고, 이 는 Bacillus subtilis HR-1019 균주가 인산 가용화 능력 이외에 도 식물의 일부 병원성 균에 대한 항균 효과를 가진 것으로 판명되어서 HR 1019 를 이용하여 미생물제제를 개발하면 인 산가용화를 통한 식물생장촉진과 식물병의 저해 효과에도 크 게 도움이 될 것으로 보여 효과적인 제품개발이 가능할 것으 로 생각되어진다. 이러한 항균성은 Bacillus $s p$ 가 large patch 병원균인 Rhizoctonia solani에 항균효과를 보여서 골프장의 Rhizoctonia solani 방제용 처리제로서의 효과도 기대된다는 연 구결과와 비슷한 효과가 기대되는 바이다[7].

\section{감사의 글}

본 연구는 동아대학교의 연구비 일부로 수행되었으므로 이 에 감사드립니다. 


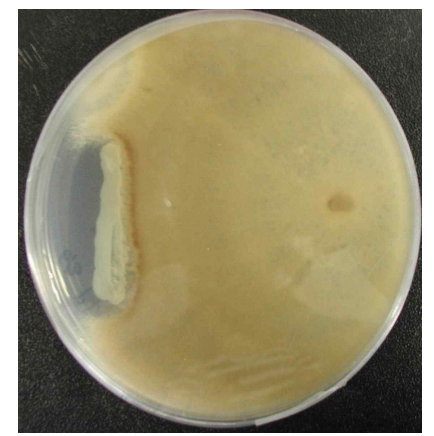

A

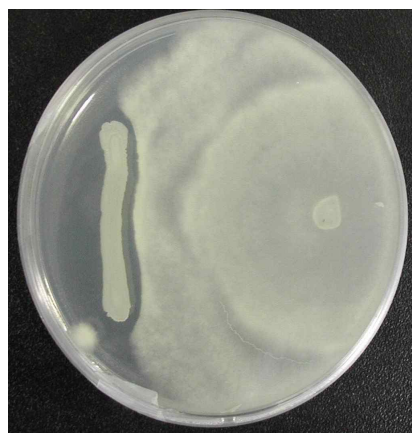

B

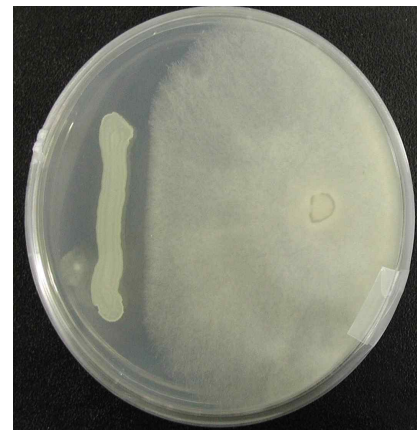

C

Fig. 6. Growth inhibition of plant pathogenic fungi by Bacillus subtilis HR-1019. (A) Botrysis cinerea, (B) Rhizoctonia solani, (C) Sclerotinia sclerotiorum

\section{References}

1. Agasimani, C., Mudlagiriyappa, A. and Sreenivasa, M. N. 1994. Response of groundnut to phosphate solubilizing microorganisms. Groundnut News 6, 5-8.

2. Dubey, S. K. and Billore, S. D. 1992. Phophate solubilizing microorganism (PSM) as inoculant their role in augmenting crop productivity India-A review. Crop Res Hisar 5, 11-17.

3. Goldstein, A. H. 1986. Bacterial mineral phosphate solubilization: Historlcal perspective and futer prospects. Am J Altern 1, 57-65.

4. Illmer, P., Barbato, A. and Schinner, F. 1995. Solubilization of hardly-soluble AlPO4 with P-solubilizing microorganisms. Soil Biol Biochem 27, 265-270.

5. Illmer, P. and Schinner, F. 1992. Solubilization of inorganic phosphates by microorganisms isolated from forest soils. Soil Biology Biochem 24, 389-395

6. Illmer, P. and Schinner, F. 1995. Solubilization of inorganic calcium phosphate-solubilization mechanisms. Soil Biol Biochem 27, 257-263.

7. Joo, W. H., Han, S. J., Choi, Y. L. and Jeong, Y. K. 2004. Antifungal compound produced by Bacillus sp. TBM912. J Life Sci 14, 193-197

8. Kang, S. C. and Choi, M. C. 1999. Solid culture of phosphate - solubilizing fungus, Penicillium sp. PS - 113. Korean J Appl Microbiol Biotechnol 27, 1-7.

9. Kim, K. K., Kim, K. H., Moon, S. S. and Kang, K. Y. 1997. Isolation and structure identification of antifungal substance from Aspergillus tereus. Agric Chem Biotechnol 40, 593-596.

10. Kucey, R. M. N. 1988. Effect of Penicillium bilaji on the solubility and uptake of $\mathrm{P}$ and micronutrients from soil by wheal. Can J Soil Sci 68, 261-270.

11. Paul, E. A. and Clark, F. E. 1989. Soil Microbiology and
Biochemistry: Academic Press, New York, U.S.A.

12. Raj, J., Bagyaraj, D. J. and Manjunath, A. 1981. Influence of soil inoculation with vesicular-arbuscular mycorrhiza and a phosphate-dissolving bacterium on plant growth and 32P uptake. Soil Biol Biochem 13, 105-108.

14. Sayer, J. A., Raggett, S. L. and Gadd, G. M. 1995. Solubilization of insoluble metal compounds by soil fungi: Development of a screening method for solubilizing ability and metal tolerance. Mycological Res 99, 987-991.

15. Son, H. J., Park, G. T., Cha, M. S. and Her, M. S. 2006. Solubilization of insoluble inorganic phosphate by a novel salt- and pH-tolerant Pantoea agglomerans R-42 isolated from soybean rhizosphere. Biores Biotechnol 97, 204-210.

16. Song, O. R., Lee, S. J., Kim, S. H.., Chung, S. Y., Cha, I. H. and Choi, Y. L. 2001. Isolation and cultural characteristics phosphate solubilization bacterium, Aeromonas hydrophyla DA57. J Korean Soc Agric Chem Biotechnol 44, 257-261.

17. Song, O. R., Lee, S. J., Lee, Y. S., Lee, S. C., Kim, K. K. and Choi, Y. L. 2008. Solubilization of insolubile inorganic phosphate by Burkholderia cepacia DA23 isolated from cultivated soil. Brazilian J Microbiol 39, 1-6.

18. Suh, J. S., Lee, S. K., Kim, K. S. and Seong, K. Y. 1995. Solubilization of insoluble phosphates by Pseudomonas putida, Penicillium sp. and Aspergillus niger isolated from Korean soils. J Korean Soc Soil Sci Fert 28, 278-286.

19. Tiwari, V. N., Pathak, A. N. and Lehri, L. K. 1993. Rock phosphate-superphosphate in wheat in relation to inoculation with phosphate solubilizing organism and organic waste. Ind J Agr Res 27, 137-145.

20. Varsha, N., Jugnu, T. and Patel, H. H. 1995. Mineral posphate solubilization by Aspergillus aculeatus. Ind J Exp Biol 33, 91-93. 
초록 : 인산가용화 활성을 갖는 바실러스 서브틸리스 HR-1019 분리와 특성

이용석 ${ }^{1} \cdot$ 박동주 $^{1} \cdot$ 김재훈 $^{2} \cdot$ 김형석 $^{2} \cdot$ 최용락 ${ }^{1} \star$

(동아대학교 생명공학과, ${ }^{2}$ (주) 해림파메틱)

본 연구의 목적은 우수한 미생물 제제 개발용 인산염 가용화 균주의 개발이다. 경작지 토양에서 분리한 인산염 가용화 균주의 특성 및 $16 \mathrm{~S} \mathrm{rDNA}$ 염기서열을 조사한 결과 Bacillus subtilis HR-1019로 동정되었다. Bacillus subtilis HR-1019는 hydroxyapatite, tri-calcium phosphate 및 aluminum phosphate 3가지의 난용성 인산염을 모두 가용화하였다. 난용성 인산염의 분해능이 최대가 되는 배양온도는 $37^{\circ} \mathrm{C}$ 이었으며, 배양초기 $\mathrm{pH}$ 가 $5.0^{\circ}$ 이었다. 탄소 원으로 glucose를 5\% 첨가시 가용화능이 높았으며, 가용화된 유리인산의 함량이 증가함에 따라 $\mathrm{pH}$ 가 크게 감소 하였다. 분리균주 HR-1019가 식물병원균에 대하여 균의 생육을 저지하는 clear zone 확인으로 항균효과를 확인 하였다. 